\title{
European identity and support for European integration: A matter of perceived economic benefits?
}

Kyklos, 67(2)

Soetkin Verhaegen, Marc Hooghe and Ellen Quintelier

\section{Summary}

Economic utilitarian theory assumes a relationship between economic benefits, support for European integration and European identity. While the relationship between economic benefits and support for European integration has already been empirically investigated, this is not the case for European identity. Therefore, we test the association between economic indicators and European identity, while performing the same analysis for support for European integration. Eight different objective and perceived economic parameters are tested, covering the whole spectrum of sociotropic, egocentric, objective and perceived benefits. The multilevel analyses on Eurobarometer data show that economic considerations are positively associated with support and European identity. This is especially the case for perceived benefits, indicating that earlier findings about perception of benefits in the study of support for European integration are valid for European identity as well.

\section{Keywords}

European identity, European integration, support for European integration, economic utilitarianism, Eurobarometer 